\title{
Non-urgent patients in an Emergency Medical Service
}

\author{
Murat Kalemoglu1, Ozcan Keskin ${ }^{1}$, Sezai Demirbas², \\ Tahir Özisik ${ }^{3}$.
}

Background: Emergency Medical Services (ES) are medical-surgical facilities where extremely ill patients, victims of accidents, intoxications and other urgent clinical situations should be rapidly and efficiently attended. However, a worldwide experience is that a large proportion of patients who require attention in an ES do not qualify as emergencies and they obstruct the possibilities of other patients that should be attended immediately. Aim: To evaluate the medical records in our ES and to assess whether patients understand what is a true emergency and which is the role of an ES. Methods: Patients attended in the ES of Haydarpasa Military Teaching Hospital in 2001-2002 were classified according to their diagnosis. A random sample of patients and relatives were surveyed about why they required medical attention in the ES. Results: 77,134 patients (39,327 female, 51\%) were attended. The most common illness diagnosed was upper respiratory tract infection (18,423 patients, $23.9 \%)$. The true emergency condition rate in patients presenting to our ES was lower (44\%) than the nonemergency condition rate. Conclusions: Improvements in public education are needed to solve this problem. Also, Primary Care facilities should be improved in order to reduce the demand for medical attention in ES by non-urgent patients (Rev Méd Chile 2004; 132: 1085-9).

(Key Words: Emergency Medical Services; Emergency Service, Hospital; First aid; Health care facilities, manpower, and Services)

${ }^{1}$ Emergency Service, Istanbul GATA Medical Faculty.

${ }^{2}$ General Surgery, Istanbul GATA Medical Faculty.

${ }^{3}$ Emergency Department, Ankara GATA Medical Faculty.

\section{Pacientes no-urgentes que consultan en un Servicio de Urgencia}

Antecedentes: Los Servicios de Urgencia son unidades médicoquirúrgicas donde deberían atenderse rápida y eficientemente pacientes graves, víctimas de accidentes, intoxicaciones y otras situaciones clínicas urgentes. Sin embargo, es una experiencia mundial que una proporción importante de los consultantes en Servicios de Urgencia no califican como emergencias, pero dificultan las posibilidades de atención para otros pacientes que deberían ser atendidos de inmediato. Propósito: Evaluar las fichas clínicas en nuestro Servicio de Urgencia y averiguar si los pacientes comprenden cuál es una verdadera emergencia y

Corresponding Address: Op. Dr. Murat Kalemoglu. GATA Haydarpasa Egitim Hastanesi. Acil Servis Sefi. 34680 Uskudar/Istanbul. Tel: 9021634626 00/2306-2111. Fax: 90216 3487880. E mail: mkalemoglu@hotmail.com 
cuál es la función de un Servicio de Urgencia. Métodos: Los pacientes atendidos en el Servicio de Urgencia del Hospital Clínico Militar Haydarpasa (Estambul, Turquía) en 2001-2002 fueron calificados retrospectivamente según sus diagnósticos. Una muestra al azar de pacientes y sus parientes acompañantes fueron encuestados sobre sus razones para solicitar atención en el Servicio de Urgencia. Resultados: Se atendieron 77.134 pacientes (39.327 del sexo femenino, 51\%). El diagnóstico más frecuente correspondió a infección del tracto respiratorio (18.423 pacientes, 23,9\%). La proporción de pacientes que calificaron como reales urgencias (44\%) fue menor que los calificados como no-urgentes. Conclusiones: Para disminuir la demanda de atención en Servicios de Urgencia por pacientes no-urgentes se requiere mejorar la educación del público y aumentar la disponibilidad de policlínicas de atención primaria, ampliando su horario de atención.

E mergency Medical Services (ES) are among the most important hospital departments. In order to serve critical patients in a much more qualified and effective way, Emergency Medical Service personnel should not be unnecessarily engaged in the care of patients with minor problems which distracts the personnel's attention, impairs their concentration, and exhausts them physically as well. Non-urgent patients (patients apt to receive regular outpatient treatment) may adversely influence the treatment of critical patients. Emergency Medical Services worldwide are subject to misuse by patients who could be treated in outpatient clinics or in primary health care settings $^{1-3}$. The aim of this study was to evaluate the degree of emergency condition in patients referred to the ES of GATA Haydarpasa Teaching Hospital during 2001-2002. For this retrospective evaluation we used the available medical records.

\section{MATERIAL AND METHODS}

Classification of the clinical diagnosis was made retrospectively by reviewing the medical charts of all the patients that presented to the ES of GATA Haydarpasa Teaching Hospital between January 1, 2001 and December 31, 2002. Each medical record had been filled-in by a triage general practitioner, a physician and a surgeon. The triage general practitioner elicited the patient's chief complaint, obtained a brief history, determined the vital signs and performed a directed examination to determine the urgency of the patient's condition. The physician and surgeon wrote the final diagnosis of the patients. We classified as ungent when treatment was required immediately» or «reatment was required within a few hours», and as non-urgent when «reatment can be safely delayed». As a brief, a non-urgent visit was defined as a patient who had a problem or condition that could wait until the following day (ie, 12 to 24 hours) for treatment. Among the 43,205 patients having the diagnosis of a non-urgent illness, 9,000 patients or accompanying relatives were asked about the reason for presentation to ES (by using a poll) and their responses were categorized.

\section{ResUlTS}

77,134 patients (39,327 male, 50,9\%) presented to the ES during the study period. A significantly higher rate of presentation was detected in patients older than 40 years compared to those younger than 40 years $(p<0.05)$. Table 1 shows some demographic characteristics of these patients. 15,498 patients (20.3\%) were hospitalized. The number of patients who qualified as having non-urgent conditions was 43,205 (56\%), whereas 33,929 (44\%) were urgent. One hundred

\section{Table 1. D emografic characteristics of patients attended at the ES}

\begin{tabular}{|lccc|}
\hline & \multicolumn{2}{c|}{ Years } & \\
& 2001 & 2002 & Total \\
\hline Female & 19.254 & 20.073 & 39.327 \\
Male & 16.953 & 20.854 & 37.807 \\
Total & 35.920 & 41.214 & 77.134 \\
0-40 years old & 23.410 & 22.920 & 46.330 \\
$>40$ years old & 12.510 & 18.294 & 30.804 \\
Total & 35.920 & 41.214 & 77.134 \\
\hline
\end{tabular}


ninety eight dead on arrival patients $(0.3 \%)$ were brought to the ES. The ES case mortality rate was $0.03 \%$ (21 cases). The causes of death are shown in Table 2. Forensic report cases were 3,253 (42\%). The most frequent single diagnosis was upper respiratory system infections (URSI), in 18,423 patients (23.9\%). The most frequently examined group was pediatrics, with 17,994 patients $(23.3 \%)$. The main reason for presentation concerning internal medicine was hypertension, with 2,706 patients (3.5\%); minor surgical interventions (operations) were done in 1,934 patients $(2.5 \%)$. The most frequently detected diagnosis of referrals are shown in Table 3.

The three most common diagnoses related to internal medicine were hypertension in 2,706 (3.5\%), arrhythmia in 1,137 (1.5\%), and intoxications in 851 (1.11\%). For surgery, the three most frequent problems were minor surgical interventions in 1,934 (2.5\%), renal colic in 1,418 (1.8\%) and head trauma in 1,182 (1.5\%). A summary of diagnosis is shown in Table 4. Among patients examined in our ES, 2,499 (3.2\%) had no sign of any illness.

The interview in randomly chosen 9,000 patients or accompanying relatives revealed that $40 \%$ of them had never thought of presenting to the primary care outpatient clinics and $35 \%$ had come to the ES because they thought that their present illness could be managed only in the ES
Table 2. Causes of on arrival mortality in patients attending an ES

\begin{tabular}{|lrrr|}
\hline & \multicolumn{2}{c}{ Years } & Total \\
& 2001 & 2002 & \\
\hline Heart failure & 6 & 5 & 11 \\
Stroke & 3 & 2 & 5 \\
Myocardial Infarction & 2 & 1 & 3 \\
Shock (Gun Shot Wound) & 1 & 1 & 2 \\
Total & 12 & 9 & 21 \\
\hline
\end{tabular}

condition. The remaining $20 \%$ of the group declared that they have always presented to ES for any health problem. Several patients said that they did this because their management could be achieved easier and faster in the ES. The presentation rate to ES of patients who did not like waiting in the outpatient clinics or were not able to make an appointment for examination was $4 \%$. The rate of presentation of patients who applied to ES due to the difficulty of obtaining permission from their work place to leave for medical examination or who depended on a family member to come back from work to be able to take the patient for medical attention in the evening was $1 \%$.

Table 3. T he most common diagnoses in the ES

\begin{tabular}{|c|c|c|c|}
\hline \multirow[b]{2}{*}{ Diagnosis } & \multicolumn{2}{|c|}{ Year } & \multirow[b]{2}{*}{ Total } \\
\hline & 2001 & 2002 & \\
\hline Upper Respiratory Tract Infection & 8.655 & 9.768 & 18.423 \\
\hline Myalgia/back pain & 1.539 & 1.765 & 3.304 \\
\hline Soft Tissue Injury & 1.369 & 1.465 & 2.834 \\
\hline Urinary Tract Infection & 1.128 & 1.354 & 2.482 \\
\hline Non-Specific Abdominal Pain & 899 & 875 & 1.774 \\
\hline Acute Bronchiolitis & 645 & 804 & 1.449 \\
\hline Peptic Ulcers Activation & 535 & 754 & 1289 \\
\hline Conversion & 500 & 695 & 1.195 \\
\hline Alcohol report & 495 & 363 & 858 \\
\hline Non-Specific Head Ache + Migraine & 485 & 371 & 856 \\
\hline Anxiety & 336 & 403 & 739 \\
\hline Luxation & 251 & 324 & 575 \\
\hline Allergy & 148 & 205 & 353 \\
\hline Chronic Obstructive Lung Disease & 138 & 193 & 331 \\
\hline
\end{tabular}


Table 4. Specific diagnoses in the study patients

\begin{tabular}{|c|c|c|c|}
\hline \multirow[b]{2}{*}{ Diagnosis } & \multicolumn{2}{|c|}{ Year } & \multirow[b]{2}{*}{ Total } \\
\hline & 2001 & 2002 & \\
\hline Hypertension & 1.247 & 1.459 & 2.706 \\
\hline Minor surgery & 891 & 1.043 & 1.934 \\
\hline Renal colic & 629 & 789 & 1.418 \\
\hline Head trauma & 588 & 594 & 1.182 \\
\hline Arrythmia & 550 & 587 & 1.137 \\
\hline Intoxication & 404 & 447 & 851 \\
\hline Gastroenteritis & 357 & 403 & 760 \\
\hline Upper Extremity Fracture & 357 & 402 & 759 \\
\hline Ischemic Heart Disease & 336 & 390 & 726 \\
\hline Acute abdomen & 333 & 392 & 725 \\
\hline Gastro Intestinal System Bleeding & 241 & 259 & 500 \\
\hline Myocardial Infarcts & 187 & 193 & 380 \\
\hline Low Extremity Fracture & 157 & 205 & 362 \\
\hline Heart Failure & 113 & 147 & 260 \\
\hline Cerebro Vascular Accident & 99 & 103 & 202 \\
\hline Multiple Trauma & 91 & 101 & 192 \\
\hline Gun Shot Wound & 53 & 67 & 120 \\
\hline Anaphylaxis & 7 & 12 & 19 \\
\hline
\end{tabular}

\section{Discussion}

Leeuwen et al, investigated the characteristics of patients who presented to ES in the year $2000^{1}$. They reported that $48 \%$ of patients did not first consider consulting family medicine, and that 30\% thought they could be better treated in the hospital. Both figures are similar to our results.

Vazquez et al, investigated the presentation rate to ES in 2000, and looked at patients who presented to ES on their own initiative ${ }^{2}$. This group of patients comprised $77 \%$ of all presenters. The reasons for patients to present to ES were as follows: $32 \%$ were unaware of the existence of other urgent care facilities other than that in the hospitals, 26\% thought that ES had better technical equipment, $21 \%$ for faster medical intervention, $11.4 \%$ thought their problem was urgent, and $8 \%$ knew other services offered less qualified service to them. These rates are also similar to our results.

Bradshaw determined that the non-urgent presentation rate was $26 \%{ }^{3}$. Among the reasons for presentation, $33 \%$ were anxious to wait, $32 \%$ claimed that the working hours in the ES were longer, and $25 \%$ of the patients felt that their illness was serious or their trauma was acute. Peterson had determined the presentation rate of non-urgent cases was $50 \%$ and did not identify any correlation regarding age, marital status, health and infectious disease ${ }^{4}$. Liu noted that more than $50 \%$ of patients presenting to ES were not urgent according to his studies over 4 years ${ }^{5,6}$.

Northington also determined that the majority of patients presenting to ES were acute cases? ${ }^{7}$. The remaining cases noted that they preferred the ES as they could get any kind of medical service in the ES. Northington noted that the use of health insurance and examination by the same surgeon every time could decrease the presentation rate of non-urgent patients.

Ersoy showed that 37,316 patients presented to ES at Mediterranean University Medical Faculty Hospital in the year 2000. Six thousand and twenty five patients (16.2\%) were admitted from $E^{8}$. This study showed different reasons for presentation than our present report. In Ersoy's report reasons for presentation to ES were: $45 \%$ reliability, $21 \%$ warm-hearted, $18 \%$ being a research hospital, $8 \%$ suggestion, $6 \%$ other causes. In 1995, $\mathrm{Hu}$ et al reported that $77 \%$ of patients managed in their ES were trauma cases ${ }^{9}$. The remaining cases were chronic cases (4\%), unimportant diagnosis (2.6\%), alcohol intake test (2.3\%), severe mental illness (2.3\%), suicides (2.2\%), and cardiac arrest in $1.8 \%$. 
Kellemann and Mc Caig commented that the reasons for presentation to ES were related to finances ${ }^{10,11}$. Patients who did not have health insurance presented to ES for nonemergent health problems.

Burnett et al reported that the main reason for presentation to ES was that patients believed that it was the best location to solve their health problem $(60 \%)^{12}$. This result is in accordance with our data. Baker et al also found similar results ${ }^{13}$.

Leeuwen et al reported that usually young adults who live close to the hospital recur to the ES immediately after minor traumas instead of to family medicine or the general medicine clinics.

Vazquez Quiroga et $\mathrm{al}^{2}$, Bradshaw $^{3}$ and Bond $^{14}$ have reported that the ES are considered by patients as fast clinics. Patients who wish to be evaluated in a short period of time present to ES. In addition, he suggested that better medical education to the ES patients must be offered to reduce their attendance to ES.

Bradshaw $^{3}$, Liu $^{4}$, Petersen ${ }^{5}$ and Gill ${ }^{15}$ notified that the non-urgent presentations are principally associated with socio-demographic factors. They

\section{REFERENCES}

1. JaArsma-van Leeuwen I, Hammacher ER, Hirsch R, Janssens M. Patients without referral treated in the emergency room: patient characteristics and motives. Nederlands Tijdschrift Voor Geneeskunde 2000; 144: 428-31.

2. Vázquez QB, Pardo MG, Fernández CG, Canals AM, Delgado NMA, Navas AM. Why do our patients go to hospital emergency departments? Atención Primaria 2000; 25: 172-5.

3. BRaDShaW YS. Emergency Medicine as Community Medicine: Non-urgent Patients Across 4 Emergency Departments in Urban Indonesia. Ann Emerg Med 2000; 35: 559.

4. Petersen la, Burstin HR, O'Neil aC, Orav ej, BRENNAN TA. Non-urgent Emergency Department Visits: The Effect of Having a Regular Doctor. Medical Care 1998; 36: 1249-55.

5. LuU T, SAyre MR, Carieton SC. Emergency medical care: types, trends, and factors related to nonurgent visits. Acad Emerg Med 1999; 6; 1147-52.

6. Lu T, WANG Q, SAyre MR. Emergency Medical Care: Types, Trends, and Factors Related to Nonurgent Visits. Ann Emerg Med 1997; 30: 411-2.

7. Northington WE, Brice JH, Zou B. 115 Utilization of the Emergency Department by Non-urgent suggested that primary health care locations should be increased in number. The larger proportion of elderly population attended in our ES is in accordance with the literature.

We determined that the non-urgent presentation rate was 56\%. Among them, 40\% had never thought of presenting to the primary care outpatient clinic and 35\% had come to the ES because they thought that their present illness could be managed only in the ES condition.

In conclusion, the number of unnecessary visits to ES could be reduced through an improvement in the cultural and educational level of the community. An expansion of primary health care facilities would also affect this process positively. Also, if the working hours of the out-patient clinics are increased, the non-urgent presentation rate in ES should decrease.

Further studies are needed, using medical documentation data, the methods to determine the number of specialists necessary for arranging the rotational system, more objective assessment of supplies and medications, and the development of more effective Emergency Medical Services.

Patients. Ann Emerg Med 2000; 36: 31.

8. ERSOY F. Acil tup ana bilim dalına üniversite ve hastane yönetiminin destegi nasl saglanabilir? 2001 Yll Acil Tıp Ana bilim dallan Koordinasyon Toplantisi Sunumu. GATA Ankara, 2001.

9. Hu SC, Tsai J, KaO WF. Three years' experience of emergency medical services in Ilan County. J Formos Med Assoc 1995; 94 (Suppl 2): 587-93.

10. KeLLERMANN L Non-urgent Emergency Department Visits: Meeting an Unmet Need, [Editorials]. JAMA 1994; 271: 1953-6.

11. McCAIG LF. National Hospital Ambulatory Medical Care Survey: 1992 Emergency Department Summary. Hyattsville, Md: National Center for Health Statistics; 1994. Advance Data From Vital and Health Statistics, № 245.

12. BuRNETT MG, Grover SA. Use of the emergency department for nonurgent care during regular business hours. CMAJ 1996; 154: 1345-51.

13. BAKER LC, BAKER LS. Excess cost of emergency department visits for non-urgent care. Health Affairs 1994; 162: 123-6.

14. Bond A. A staffed ED assessment room: Impact on wait times for nonurgent patients at a Saudi Arabian hospital. J Emerg Nurs 2001; 27: 394-5.

15. G匹 JM. Non-urgent use of the emengency department: Appropriate or not? Ann Emerg Med 1994; 24: 953-7. 